Prethodno priopćenje UDK 11(045)

1 Schelling, F. W. J.

doi: $10.21464 /$ fi 40106

Primljeno 19. 9. 2019.

\title{
Ivan Smiljanić
}

Osječka ulica 205, HR-33000 Virovitica ivan.smiljko@gmail.com

\section{Filozofija kao duhovna znanost u Schellingovu srednjem razdoblju}

\begin{abstract}
Sažetak
U ovom radu prikazuje se razvoj nužne ideje sistema, koji je istinska forma filozofije kao znanosti, onako kako je to izvedeno u srednjem razdoblju Schellingove misli, osobito u okviru njegovih Erlangenskih predavanja iz 1821. godine. Schelling prikazuje kako apsolutni subjekt, krećući se od jednoga obličja znanja prema drugomu, gradi totalni sistem uzdignut ponad svih partikularnih sistema i tako stječe samospoznaju koja je pravi sadržaj filozofije kao znanosti. Istinsko filozofijsko znanje opire se kretanju apsolutnoga subjekta, čime se čovječja svijest kao princip partikularne svijesti izgrađuje kao svijest apsolutnog subjekta koji je princip univerzalne svijesti. Samo filozofija kao znanost može čovjeka voditi i dovesti do najvišega znanja o svijesti apsolutnoga subjekta kao njegove vlastite svijesti.
\end{abstract}

\section{Ključne riječi}

Friedrich Wilhelm Joseph Schelling, apsolutni subjekt, filozofija, znanost, mudrost, sloboda, sistem, ekstaza, svijest, čovjek, duh

\section{Uvod}

Srednje ili prijelazno razdoblje filozofije Friedricha Wilhelma Josepha von Schellinga (1775. - 1854.) predstavlja važnu razvojnu točku njegove misli jer u sebi sabire njegove uvide iz transcendentalne filozofije, filozofije identiteta i dobā svijeta te produktivno nastavlja tu misao u njegovu kasnu filozofiju mitologije i objave. ${ }^{1}$ To prijelazno razdoblje pripada münchenskom periodu Schellingova života i rada, koje traje od njegova preseljenja iz Würzburga 1806. godine, pod političkim pritiskom napoleonskih ratova, pa sve do 1841. godine i početka njegovih predavanja u Berlinu. Ono ujedno predstavlja svojevrsnu točku postupnog prijelaza u filozofiju mitologije i objave, koja bi u pojmu Boga mogla vidjeti nužnu povezanost zbiljnosti i slobode.

»Njihovi glavni predmeti pitanja su o pravoj zbiljnosti, slobodi i Bogu. Schelling sada traži 'egzistirajućega' Boga. 'Negativna filozofija' Kanta, Fichtea i Hegela dovela je samo do Boga u ideji. Ona nije našla pravu zbiljnost ni slobodu, pa zato ni pravoga Boga. $\ll^{2}$

Ovaj je rad nastao na temelju istraživanja inicijalno provedenih u sklopu pisanja diplomskog rada pod naslovom »Filozofija kao znanost u Schellingovim Erlangenskim predavanjima«, obranjenog u srpnju 2019. godine na Odsjeku za filozofiju Filozofskog fakulteta Sveučilišta u Zagrebu.
Johannes Hirschberger, Geschichte der Philosophie: Neuzeit und Gegenwart, sv. 2, Verlag Herder, Freiburg im Breisgau ${ }^{11} 1980$., str. 377 . 
Schelling je odbacio pokušaje negativne filozofije i upustio se u pothvat stvaranja takve filozofije koja bi mogla biti označena kao pozitivna.

»Schelling je, uvidjevši kroz Hegela svu irealnost 'čisto racionalne filozofije', prvi postavio zahtjev za jednom, ne puko idealnom i u tom smislu 'negativnom' filozofijom, već za jednom idealnom i ujedno realnom, apriornom i ujedno aposteriornom, umskom i ujedno empiričkom - pozitivnom filozofijom - ali je odmah bio svjestan kako bi takav vid filozofije bio samim sobom jedna - povijesna filozofija - geschichtliche Philosophie. $\aleph^{3}$

Ipak, uvijek treba imati u vidu da Schelling nikada nije postavio gotov ili zatvoren sistem, nego je postavio ono što on sam naziva tek ulomcima jedne cjeline. Stvaranje filozofijskoga sistema nije tek izraz duha jednoga vremena, nego se ujedno pokazuje i kao nužnost svakoga doba. Schellingovo je doba stoga i obilježavalo bujanje raznih sistema koji će biti predmet njegove kritike, a mnogima će od njih čak i odricati pojam sistema, dok nijednoga od njih nije smatrao ni približno dovršenim totalnim sistemom. Naime, izgradnja i izobrazba filozofijskoga sistema ne ovisi samo o naporima čovjeka kao pojedinca ili čak i čitavoga ljudskog roda nekoga vremena jer ono što Schelling naziva sistemom svijeta postoji već i prije čovjeka.

»U Njemačkoj, gdje filozofijski sistem postaje predmet literarne industrije, i tako mnogi kojima je priroda uskratila razum čak i za svakodnevne stvari vjeruju da su pozvani na sufilozofiranje, vrlo je lako probuditi neko krivo mnijenje, da, čak zanos. $\ll^{4}$

Naime, istraživači su smatrali nužnim pravilno smjestiti spise poput Erlangenskih predavanja, Dobā svijeta, Stuttgartskih privatnih predavanja ili Filozofijskih istraživanja o bitstvu čovječje slobode i predmetima koji su s time u svezi u kontekst cjelokupne Schellingove filozofije, koja nije smatrana jednoznačnom u svom dugom trajanju pa je često bila dijeljena na nekoliko razdoblja. Tako, po Zellerovoj interpretaciji, kod Schellinga postoje četiri stupnja filozofije (transcendentalni idealizam i filozofija prirode, filozofija identiteta, prijelaz k teozofiji te na kraju pozitivna filozofija). Kuno Fischer razlikuje četiri odsjeka, a to čini i Nicolai Hartmann, samo u pet perioda. Eduard von Hartmann pak razlikuje samo dva temeljna perioda Schellingova filozofiranja: filozofija identiteta od 1797. do 1806 . godine i pozitivna filozofija od 1806. do 1854. godine. ${ }^{5}$

»Tome nasuprot H. F. W. Hinrichs već 1843. spominje one koji govore 'da su princip i metoda od početka do kraja ostali isti', H. Heine ističe 'temeljnu ideju', I. H. Fichte upozorava 1850. na 'temeljni zor, koji ga (Schellinga) prati kroz različite razvojne epohe njegova mišljenja' i napokon na kontinuitetu inzistiraju naročito W. Szilasi, W. Schulz, Chr. Wild, H. Fuhrmans. «

Oštre kritike upućene Schellingu, koje su ga upravo zbog različitih periodizacija pokušavale diskreditirati kao filozofijski nestalnoga autora, mogu izgubiti ponešto od svoje oštrine ako se uvidi da Schellinga kroz čitavo njegovo filozofiranje prate stalni motivi.

»Suprotno raširenom mnijenju, koje se nadovezuje na protejsku sliku on nikada nije zaboravan, tako da ništa ne ispušta, ne ispravlja i ne odbacuje nesvjesno, te je sukob sa sobom samim prvi pokretač jednoga istovremeno genijalnog i promišljenog, promozganog djela, posebno u drugoj fazi njegova stvaranja. « ${ }^{7}$

Velikim imenima filozofije teško se uopće ikada može pripisati nešto takvo kao što je mijenjanje perspektive ili mišljenja, koje je ipak vjerojatno prije pokazatelj površnosti i nerazumijevanja takvoga prosuditelja velikih filozofa.

»Ipak, kao i kod svake velike i prave filozofije, tako se i ovdje jednom dublje ponirućem i razumijevajućem pogledu postupno sve jasnije ocrtavaju obrisi jedinstvene temeljne strukture cjelokupnoga djela i nepovratno nestaje privid beskonačne raspršenosti, fragmentarnosti i rap- 
sodičnosti, koji ovdje možda doista više no drugdje može početno određivati sliku što je pružaju mnoga, mnogostruko ponavljana i iznova započinjana Schellingova djela. $\ll^{8}$

\section{Nužnost sistema}

Tek s nastupom razdoblja njemačkoga klasičnog idealizma ili klasične njemačke filozofije može se uopće govoriti o pojmu filozofijskoga sistema u najstrožem smislu, iako naznake sistematičnosti postoje i u ranijim filozofijama, npr. Platona i Aristotela. Sam pojam sistema nužno je vezan uz pojam znanosti i upravo zato filozofija kao apsolutna znanost odnosno znanost onoga apsolutnoga može biti promatrana samo u njenom sistemu. Prema Schellingu, nije teško definirati što je to sistem kao takav. Sistem on općenito označuje i određuje kao uređenu cjelinu mnogih članova. Upravo zato što sistem pretpostavlja cjelinu, a ne tek pojedinačne momente, Schelling može reći kako je glavni sadržaj i predmet Erlangenskih predavanja o naravi filozofije kao znanosti cjelina sklopljena od početka, sredine i kraja, a ne tek jedan od dijelova

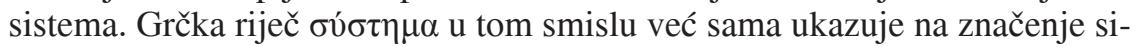
stema kao sklopa mnoštva članova koji su međusobno uvjetovani i uzajamno pretpostavljeni. $^{9}$

Nijedan pojedinačan član sistema ne može izgubiti snagu vlastite pozicije u sistemu, a da to ne utječe na samu sistemsku cjelinu. Svaka moguća promjena među članovima utječe na promjenu u čitavom sistemu, a promjena sistema kao cjeline utječe na sve njegove članove. Jednako kao što dio postaje dio tek po cjelini jer je u odnosu spram nje, tako su i članovi u međusobnom odnosu jedni spram drugih. Članovi svakog sistema tek u njemu pronalaze svoje istinsko i pravo mjesto, a sistem kao sistem može biti uistinu pojmljen tek po svim svojim pojedinačnim članovima. Budući da je svaki član sistema u odnosu uzajamnoga utjecaja sa svakim drugim, time ujedno gradeći njihov međusobni odnos s cjelinom sistema, promjena u jednom članu ne mijenja samo cjelinu nego i sve ostale članove cjeline. Povezanost članova omogućena je nerazrješivom vezom među njima u cjelini sistema. Dio sistema ne može opstojati bez cjeline sistema, baš kao što ni organi poput srca ili pluća ne mogu živjeti odvojeno od sklopa organizma. ${ }^{10}$

3

Marijan Cipra, Metamorfoze metafizike, Matica hrvatska, Zagreb ${ }^{2} 1999 .$, str. 103.

4

Friedrich Wilhelm Joseph Schelling, Stuttgarter Privatvorlesungen, Vicki Müller-Lüneschloß, Felix Meiner, Hamburg 2016., str. 63.

5

Usp. Branko Despot, »Uz ovaj izbor«, u: Friedrich Wilhelm Joseph Schelling, O bitstvu slobode, preveo Branko Despot, Cekade, Zagreb 1985., str. 7-12, str. 9.

6

Ibid., str. 9.

7

Xavier Tilliette, »Schelling između gnoze i filozofije«, u: Filozofska istraživanja 8 (1988) 1, str. 61-71, str. 64
Damir Barbarić, »Friedrich Wilhelm Joseph Schelling«, u: Damir Barbarić (ur.), Hrestomatija filozofije, sv. 6, Filozofija njemačkog idealizma, Školska knjiga, Zagreb 1998., str. 569.

9

Usp. Friedrich Wilhelm Joseph Schelling, Initia philosophiae universae - Erlanger Vorlesung WS 1820./21., Horst Fuhrmans (ur.), H. Bouvier u. Co. Verlag, Bonn 1969., str. 1 (u daljnjem tekstu: IPU).

10

Usp. ibid., str. 2.

11

Friedrich Wilhelm Joseph Schelling, »Filozofijska istraživanja o bitstvu čovječje slobode i predmetima koji su s time u svezi«, u: Fried- 
»U sistemu ima svaki pojam svoje određeno mjesto na kojem on jedino važi, a koje određuje $\mathrm{i}$ njegovo značenje, kao i njegovu limitaciju. Tko se sad ne upušta u ono unutrašnje, nego samo najopćenitije pojmove izdvaja iz sveze, kako bi taj mogao pravilno prosuditi cjelinu? «11

Schelling pripada epohi njemačke klasične filozofije po svojem temeljnom pojmu slobode, koji nije u proturječju s pojmom sistema.

»Traži li se jedna središnja i ključna ideja koja vlada cjelokupnim idealizmom i bitno ga obilježuje, mogla bi prije svih ostalih jamačno biti pronađena u ideji slobode. $\ll^{12}$

Schellingu je zato bitno naglasiti kako ne može postojati nikakve nesročnosti između pojma sistema i pojma slobode. Pojam slobode upravo mora biti jedna od središnjih gospodarećih točki totalnoga sistema jer on nije tek podređeni ili sporedni pojam. Tek je posljedica mita da je pojam slobode na neki način nespojiv s pojmom sistema, u što su vjerovali mnogi pobornici panteizma koji su ga pogrešno shvaćali kao isključivo fatalistički i deterministički sistem.

»Ili ako se to mni, da se pojmu slobode protivi pojam sistema uopće i po sebi: onda je čudnovato da, budući da je individualna sloboda ipak na neki način u svezi sa cjelinom svijeta (svejedno, mislila se ona realistički ili idealistički), onda mora barem u božanskome razumu postojati nekakav sistem s kojim sloboda zajedno opstoji. «13

Sistem se uspostavlja uzajamnim procesom između nositelja kretanja kroz sistem, dakle apsolutnoga subjekta i čovjeka u njihovu međusobnom reflektirajućem kretanju, a koje ima tri glavna momenta. Prvi se moment može opisati kao ishodišna točka kretanja (terminus a quo - najraniji mogući vremenski trenutak nekog zbivanja), drugi kao cilj (terminus ad quem - najkasniji mogući vremenski trenutak nekog zbivanja), a treći kao posredujuća točka (Vermittlungspunkt). ${ }^{14}$ Prvi moment Schelling opisuje kao onaj u kojem apsolutni subjekt na jednoj strani uživa u potpunoj i apsolutnoj nutarnjosti. Takvo stanje Schelling označuje kao A. Nasuprot tom A postoji svijest u stanju iskonskoga neznanja, tj. B. Iz stanja apsolutne nutarnjosti apsolutni subjekt, takoreći primoran nužnošću vlastite naravi, kretanjem želi dospjeti do stanja apsolutne izvanjskosti, tj. iz stanja znanja želi prijeći u stanje neznanja. Tako dolazi do drugoga momenta kada subjekt postaje objekt, odnosno A postaje $\mathrm{B}$ ( $\mathrm{A}=$ B). U istom se hipu događa prelazak apsolutne izvanjskosti kao naprosto ne znajućega u stanje nutarnjosti čistoga znanja, odnosno B postaje A $(B=A)$. Povratak iz B u A, shvaćen kao B = A, uistinu je povratak iz ne-duhovnoga u duhovno, ali sada na način povezanosti duhovnoga i ne-duhovnoga:

»Prelazak iz subjekta u objekt reflektira se kroz prelaženje iz objekta u subjekt. Upotrebljava se stoga izraz refleksija. Kao što se predmet odražava u vodi, upravo tako stoji apsolutni subjekt u obrnutom odnosu spram svijesti. « 15

\section{Apsolutni subjekt}

Sam pojam apsolutnoga subjekta ima i svoju predschellingovsku povijest, ali vezan je, gledano povijesno-filozofijski, za novovjekovno filozofiranje. Apsolutni subjekt isto tako i kod Schellinga dobiva svoje specifično značenje i mjesto u sistemu. Kao što je nutarnji nerješivi spor i proturječje unutar čovječjega znanja izvanjski razlog za nužnost nečega takvoga kao što je sistem, tako je isto i nutarnja mogućnost sistema pokazana u Schellinga kao subjekt. Apsolutni subjekt jest cjelina koja u sklad i sukladnost dovodi i razrješava svaki od pojedinih partikularnih sistema, koji se međusobno naravno znatno razlikuju i proturječe. Subjekt je cjelina koja omogućuje sklad pojedinačnih sistema u totalnom sistemu. Nutarnja mogućnost sistema moguća je isključivo pod dvjema pretpostavkama. Prva od njih je sveopća ideja napredovanja 
odnosno kretanja, bez ikakve naznake mogućega stajanja na bilo kojem od pojedinačnih momenata. To je nužno jer takvo neprestano kretanje drži odvojenima proturječne tvrdnje i momente sistema. Tako ne mora biti nesročno da $\mathrm{u}$ jednome momentu napredovanja apsolutnoga subjekta tvrdnja $\mathrm{A}=\mathrm{B}$ bude istinita, a u drugome pak $\mathrm{A}=$ ne-B. ${ }^{16}$

»Koliko se izvjesno bitstvo znanosti sastoji u napredovanju, toliko nužno njeno prvo postavljanje jest postavljanje proturječja. «17

Pitanje o bitstvu apsolutnoga subjekta zapravo je isto kao i pitanje o principu filozofije. Ono što princip filozofije mora biti ako hoće biti princip upravo je zadržavanje statusa principa u svim momentima razvoja sistema. Naime, princip filozofije ne smije biti samo princip nekoga početka ili početni princip, koji potom ne bi do kraja prolazio kroz sve momente sistema. On mora biti princip kroz sve momente prolaska: na početku, na sredini i na kraju. Promišljanje cjeline svih momenata prolaska principa jest naporan zadatak koji stoji pred principom partikularne svijesti.

»Nije bilo komu dano znati kraj, malo je onih kojima je dano vidjeti prapočetke života, još manje je onih kojima je dano promisliti cjelinu od prve do posljednje stvari. «18

Ono što je u predschellingovskoj filozofiji bilo pogrešno jest neispravno razumijevanje ideje principa tek kao prve i najviše karike u lancu postavki koje se potom izvode iz te početne postavke.

»Naime, budući da se filozofiju promatralo samo kao lanac slijedećih odvojenih postavki, predočavalo se, da bi moralo biti jedne najviše karike u tom lancu - jedne prvotne postavke iz koje zatim slijedi neka druga, iz te potom neka treća itd. ${ }^{19}$

Primjeri takvoga neispravnog razumijevanja svakako su Descartes sa svojim »Mislim, dakle jesam« i Fichte s »Ja sam Ja«. Ako se na taj način započne izgradnja jednoga sistema, onda to nužno rezultira tek jednim partikularnim sistemom, koji doduše ima u sebi sadržane velike istine i znanje, ali i dalje nema obuhvaćenu cjelinu svega što jest. ${ }^{20}$

Zahtjev da se jasno i čvrsto definira što apsolutni subjekt uistinu jest, postavljen je pitanjem o samoj njegovoj naravi. Svaki pojam, pa tako i onaj apso-

rich Wilhelm Joseph Schelling, O bitstvu slobode, preveo Branko Despot, Cekade, Zagreb 1985., str. 13-67, str. 64.

12

Damir Barbarić, »Idealizam slobode«, u: Damir Barbarić (ur.), Hrestomatija filozofije, sv. 6, Matica hrvatska, Zagreb 1998., str. 26.

13

F. W. J. Schelling, Filozofijska istraživanja o bitstvu čovječje slobode, str. 17.

14

Usp. F. W. J. Schelling, IPU, str. 43.

15

F. W. J. Schelling, IPU, str. 44; Friedrich Wilhelm Joseph von Schelling, »Über die Natur der Philosophie als Wissenschaft«, u: Friedrich Wilhelm Joseph von Schelling, Sämmtliche Werke, sv. 9, Karl Friedrich August Schelling (ur.), J. G. Cotta, Stuttgart; Augsburg 1861., str. 209-246, str. 232 (u daljnjem tekstu: SW I/9).
16

Usp. F. W. J. Schelling, IPU, str. 15.

17

Friedrich Wilhelm Joseph Schelling, Dobā svijeta, preveo Kristijan Gradečak, Naklada Breza, Zagreb 2016., str. 27.

18

Ibid., str. 15.

19

F. W. J. Schelling, IPU, str. 16; F. W. J. Schelling, SW I/9, str. 215-216.

20

Usp. F. W. J. Schelling, IPU, str. 16; usp. F. W. J. Schelling, SW I/9, str. 216.

21

F. W. J. Schelling, IPU, str. 17; F. W. J. Schelling, SW I/9, str. 217. 
lutnoga subjekta, mora biti definiran, ali se kod njega nailazi na nepremostiv problem. Naime, prilikom svakog definiranja nužno se mora moći definirati nešto na definitivan način, a apsolutni se subjekt može definirati samo na taj način da se o njemu dade reći kako može biti uvijek i drugo od onoga što je o njemu isprva rečeno. Apsolutni subjekt nije ništa pojedinačno ni mirujuće.

»On je u jednom nezadrživom kretanju, ni u jedno obličje nije zatvoren, on je ono inkoercibilno [das Incoercible], neshvatljivo, uistinu ono beskonačno. $\ll^{21}$

Time je postignut negativno određeni pojam o njemu, ali još uvijek ne i neki pozitivni. Negativnim putem ne može se doći do pojma apsolutnoga subjekta jer o apsolutnom subjektu ne može ništa biti iskazano tako da se o njemu ne bi mogla izreći i suprotna tvrdnja, a imenujući ga onim indefinibilnim (das Indefinible) to se učinilo i tako se uistinu pokazalo kao neprimjeren put istraživanja. Apsolutni subjekt pokazuje se zapravo kao vječna i apsolutna sloboda sama jer apsolutni subjekt po sebi ima slobodu upustiti se u neko obličje partikularnoga znanja u svom kretanju i potom iz njega izaći. Nužno je i ovdje dobro razlučivati stvari jer apsolutni subjekt nije neko od slobodnih bića kojemu bi sloboda pridolazila izvana poput nekog svojstva, nego on jest sama ta vječna sloboda. Tako protumačena sloboda nije mišljena kao puka neovisnost o vanjskim određenjima. Upravo zbog toga Schelling uviđa kako apsolutni subjekt ujedno i nije apsolutna sloboda:

»On sam mora biti slobodan od slobode, a ako bi on to bio nužno, da ostane apsolutna sloboda, onda bi bio ograničen. On ne smije biti samo slobodan nego mora također biti i slobodan da bude sloboda sama. $\ll^{22}$

Jednom kad se apsolutni subjekt upustio u neko obličje, kada je izašao iz stanja nepomućene slobode, više nije kadar neposredno se vratiti u izvorno stanje, nego je prisiljen to učiniti posredno, naime, upuštajući se i odmah potom izlazeći iz pojedinih obličja na dugome putu povratka k samome sebi.

»Ali ne bih to tako htio izraziti: on je ono što je slobodno poprimiti obličje. Jer bi se tako ta sloboda pojavila kao svojstvo koje još pretpostavlja neki od nje različiti i neovisni subjekt - nego je sloboda bitstvo subjekta, ili on je sam ništa drugo doli vječna sloboda. $\ll^{23}$

Krajnje određenje apsolutnoga subjekta za Schellinga počiva u mudrosti. Budući da u tom izvornom i iskonskom stanju apsolutnoga subjekta leži daleko više od pukoga znanja, naime leži objektivno proizvođenje i rađanje, treba u jeziku naći adekvatan pojam kojim bi se takvo znanje razlikovalo od onoga pukoga znanja. To puko ili subjektivno znanje samo je jedno idealno ponavljanje izvornoga znanja. Naime, ono je znanje kojemu očigledno nedostaje upliv u svijet objektiviteta te stoga izrazom »mudrost « Schelling pokazuje razliku između pukoga znanja i znanja koje je djelujuće. Mudrost, za razliku od idealnoga znanja, pokazuje se prije svega u činu, djelovanju i životu. Mudrost je oblik praktičkoga znanja u najvišem smislu. Tako se naposljetku apsolutni subjekt kao vječna sloboda pokazuje i kao mudrost u najvišem smislu. ${ }^{24}$ Filozofija nije duhovna djelatnost u kojoj bi čovjek ikada mogao biti ono znajuće, nego je on ono koje se mudrosti, koja rađa znanje, uvijek suprotstavlja kako bi je uspješnije mogao sputavati, priječiti i reflektirati. Upravo takvim postupkom čovjek može u samom sebi roditi slobodno mišljenje koje ponovno želi dospjeti u davno napušteno iskonsko jedinstvo s mudrošću. Ta je mudrost uistinu gospodarica svih umijeća jer je ona duh koji kroz sve prolazi kao vječna sloboda. Mudrost je uistinu pravi oblik znanja jer je jedno, a ipak mnogo, čime je u njoj totalna koherentnost koja ne dopušta nikakav oblik nepovezanosti ili nejedinstva njenih pojedinih momenata. Pozivajući se na Knjigu mudrosti, Schelling ustvrđuje kako je mudrost duh koji je razborit i 
jedincat, a ipak unatoč tomu mnogolik. Mudrost kao duh koji prolazi kroz sve ostale duhove, čini ih tako razboritima, čistima i bistrima, ali prolazi i kroz najviši duh, naime samo božanstvo.

»[Z]ato što božanstvo samo, premda je čistoća sama, nije čistije od nje - ona prolazi kroz sve duhove zato što je ona ono od svega najokretnije ili, kako se to u grčkom izvornom tekstu kaže:

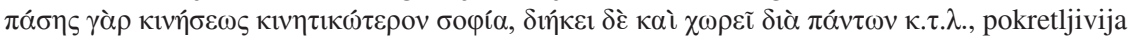
od svega pokretnoga $(\ldots) \cdot \ll^{25}$

\section{Filozofija kao duhovna znanost}

Napredovanje apsolutnoga subjekta kroz sve momente sistema uistinu je u filozofiji ono najteže jer sistem filozofiji uvijek predstavlja upravo ono najbitstvenije, a u Schellingovo je vrijeme bio i ono najtraženije i najcjenjenije.

»Ništa se u filozofiji ne da predati kao čista gotova postavka: samo se postupno dade roditi potpuni pojam. $\ll^{26}$

Filozofija svoj sistem još uvijek nije dotad izgradila jer sve do Kanta nije postojala svijest o nužnosti nacrta takvoga pothvata pa je ujedno njegova velika zasluga što je svojom arhitektonikom uma pripravio ozbiljenje mogućnosti konačne izgradnje jednoga istinskog sistema. Za Kanta arhitektonsko jedinstvo uma važi kao shema ideje znanosti odnosno kao sistem koji je jedinstvo raznolikih spoznaja pod nekom idejom. To ujedno znači kako znanost nije nikakav skup ili agregat partikularnih stajališta kao mehaničkih dijelova, nego upravo sistem kao organska cjelina momenata. Ipak, apsolutna znanost u svojoj formi sistema možda upravo i jest samo forma lišena bitstvenog sadržaja. ${ }^{27}$ Cjelina znanosti još od Aristotela važi kao cjelina istinitih sudova. Tradicija započeta u Aristotela svoju kulminaciju doživjela je u Hegela, koji može pobjedonosno zaključiti u predgovoru Fenomenologiji duha kako je ono istinito ujedno ono cijelo. ${ }^{28}$ Pitanje koje se na ovom mjestu otvara, a u koje ne možemo dublje ulaziti, ono je o sukladnosti savršene forme filozofijskoga sistema i njegova sadržaja, odnosno odgovara li savršena forma filozofijskoga sistema doista svome sadržaju.

Ta težnja i nastojanje, tako svojstveni oko izgradnje i sistematiziranja u filozofiji, mogu rezultirati udaljavanjem i stranputicom, ali to ipak ostaje cilj akademskoga studija. Koliko toga ovisi o uspješnosti takvog pothvata, kazuje sam Schelling:

»Osnovne crte cjelokupne filozofije su sada ono najbitstvenije, ali i najteže. To je jedna borba na život i smrt i čovjek je na nju pozvan. To je borba koja uzima u obzir naš čitav karakter i u njoj se trebamo ojačati i upoznati našu snagu koja je dorasla čitavoj beskonačnosti. $\ll^{29}$

22

F. W. J. Schelling, IPU, str. 21.

23

F. W. J. Schelling, IPU, str. 21; F. W. J. Schelling, SW I/9, str. 220.

24

Usp. F. W. J. Schelling, IPU, str. 26; usp. F. W. J. Schelling, SW I/9, str. 223.

25

F. W. J. Schelling, IPU, str. 65; F. W. J. Schelling, SW I/9, str. 243-244. Radi se o Mudr. 7,24: »Jer je mudrost gibljivija od svakog gibanja, ona proniče i prožima sve svojom čistoćom.«
26

F. W. J. Schelling, IPU, str. 50; F. W. J. Schelling, SW I/9, str. 234.

27

Usp. M. Cipra, Metamorfoze metafizike, str. 17.

28

Usp. Georg Wilhelm Friedrich Hegel, Phänomenologie des Geistes, u: Werke in 20 Bänden, sv. 3, Eva Moldenhauer, Karl Markus Michel, Suhrkamp, Frankfurt am Main 1970., str. 24.

29

F. W. J. Schelling, IPU, str. 3. 
Izvorna sloboda kao stanje apsolutnoga neznanja i praistine apsolutnoga subjekta postala je izgubljena onoga časa kada je apsolutni subjekt iz takvoga stanja izašao i ušao u partikularni moment totalnoga sistema. Čovjek, koji u sebi mora ponavljati taj oblik kretanja subjekta, duboko u sebi osjeća gubitak te izvorne $\mathrm{i}$ iskonske slobode.

Taj veliki žal za nekadašnjim jedinstvom s iskonom, koji čovjek osjeća u sebi kao kretanje apsolutnoga subjekta prema samom sebi, nalazi svoj izričaj u svim duhovnim djelatnostima čovjeka, a u jedinstvu materije i forme s obzirom na zor ponajprije u umjetnosti.

»Izgubljena je ta izvorna sloboda, a najstarije prisjećanje čovjeka jest žalost za gubitkom te slobode; da je sve svezano za bitak i da je sve sišlo od izvorne slobode. Majstorska djela Grka dokazuju to i sva nose žig žalosti za gubitkom izgubljene slobode, a neka je sjeta prelivena preko čitave prirode. U uzvišenim je tvorevinama Grka sloboda stupila u obličje i zato su one najviša tvorevina. $\ll^{30}$

\section{Schelling u svom Spisu o slobodi filozofiju također određuje kao znanost:}

»Filozofija kao znanost tu se određuje kao 'dijalektička filozofija', koja počiva na 'znanstvenom oduhovljenju'.«31

Mišljenje koje se kroz dijalektiku uspostavlja uvijek je nužno dijalektičko zbog same dvostruke pozitivno-negativne naravi samoga mišljenja. Dualističko razlikovanje između materije i forme, koje sprječava ulazak u istinsku filozofiju, razrješuje se sistemom. U svakom istinskom sistemu materija nastaje istodobno s formom pa kod Schellinga ne može biti govora o neodgovaranju sadržaja sistema apsolutnoj i savršenoj formi u koju se taj isti sadržaj zaodijeva. Zato Schelling može tvrditi:

»Tko filozofira, taj također ima i filozofiju. $\ll^{32}$

Filozofiji kao duhovnoj znanosti potreban je instrument spoznavanja, a to je razum pa je upravo stoga bitno raščistiti odnos uma i razuma. Naime, neispravno mnijenje o razdvojenosti filozofije i općega čovječjega razuma rezultat je posve krivog razumijevanja same riječi »opće«. Pod time se nikada ne smije pomišljati samo običan razum, u smislu zdravoga razuma, nego opće u smislu sveopćega. Ne postoji stoga nijedna istina koja se ne bi izravno doticala i čovječjega općeg razuma. Istina ne može nikada biti suprotstavljena razumu, a u slučaju da je tomu tako, kao što je to primjerice slučaj s Kopernikovom hipotezom heliocentričnoga sustava, to onda nije problem ni istine ni razuma, nego neispravnog shvaćanja što razum uistinu jest. Povezano s time svakako je od Kanta pa nadalje pogrešno razlikovanje između uma i razuma. Posljedica je toga za filozofiju bilo proglašavanje razuma nepotrebnim i sputavajućim za djelatnost filozofiranja. Uistinu, nema nikakve znanosti bez upotrebe razuma, pa ni filozofije. Treba uvidjeti da između uma i razuma ne može nikada biti nekakvoga proturječja ili dualizma.

Kada se i pita primjerice što je subjekt filozofije kao znanosti, onda se ne može pronaći ništa adekvatno s čime ga se može prispodobiti i tako olakšati potragu za njim. Onaj tko se hoće uslijed procesa traganja za njim uistinu i uzdignuti do njega, mora se ponajprije uzdignuti iznad svega što je definirano jezikom. Slobodna znanost kao cilj takve potrage ne može biti obuhvaćena niti shvaćena definicijama. Ono što je obuhvaćeno definicijom na taj je način nužno konačno biće, a ako se hoće uzdignuti do onoga beskonačnoga, onda se svaki oblik konačnosti mora napustiti. Upravo je to čovjeku najveći i ujedno najteži korak. To je promjena i zaokret koji pogađa njegov duhovni život, ali 
je to uistinu moguće. Schelling to pojašnjava na primjeru ćudorednoga života u kojem se može iznenadno i naglo promijeniti dotadašnji način življenja i započeti jedan sasvim novi. Taj zaokret zapravo je stupanje u stanje izvornoga i iskonskoga neznanja. Prema Schellingu, tu je za filozofiju sasvim primjereno upotrijebiti Kristov novozavjetni izrijek:

»Ako ne postanete kao djeca, nećete doći u kraljevstvo nebesko. ${ }^{33}$

\section{Rađanje filozofije kao znanosti}

Apsolutni subjekt kao vječna sloboda napušta vlastitu poziciju vječne slobode i upušta se u pojedino obličje iz kojega potom odmah istupa prelazeći u neko drugo. Na taj način sloboda se vraća samoj sebi, no ne više kao ta sloboda, ali opet ni kao različita od nje. Sloboda koja se vraća samoj sebi ni u kojem slučaju nije ista sloboda, kao da bi tu bila riječ o pukoj philosophia perennis, nego se vraća kao ona koja je sada slična samoj sebi. Riječ je u tom slučaju o slobodi koja je prestala biti sloboda prelazeći u razna obličja, a potom se ponovno vraća samoj sebi iz ne-slobode kao ona koja je znajuća jer ima iskustvo prolaženja kroz neznanje u obliku pojedinačnih obličja. Upravo se to može nazvati istinskim oblikom znanosti koja prati kretanje subjekta, ali ne kao nečega njoj izvanjskoga, nego uistinu kao njenog nutarnjeg bitstva.

»Kako se isprva ta vječna sloboda zatvara u neko obličje - u neki bitak, i kako se ona konačno ponovno probija u vječnu slobodu kroz sve prolazeći i ni u čemu ne ostajući - kao vječno hrvajuća, ali nikada pobijeđena, stalno neprevladana snaga, koja svaku formu u koju se zatvara, uvijek ponovno sama sažeže, dakle iz svake ponovno ustaje poput feniksa i preobražava se smrću u plamenu - to je sadržaj najviše znanosti. «34

Znanost je proizvedena upravo takvim u čovjeku reflektiranim kretanjem apsolutnoga subjekta iz stanja apsolutnoga ne znajućeg neznanja preko znanja te naposljetku sve do povratka u stanje neznanja, ali sada kao znajućega neznanja.

»Čitava znanost mora biti jedno napredujuće samoprikazivanje one vječne slobode.«35

Schelling s pravom upozorava kako ovdje nije riječ ni o kakvoj znanosti koja bi se mogla imenovati čovječjom jer je riječ o prikazu sistema u onome idealnom, zbog čega je za Schellinga moguće uopće govoriti o nečemu takvome kao što je apsolutni subjekt (gdje još uvijek ono idealno pripada subjektivnome polu, a realno objektivnome). Apsolutni subjekt kao princip filozofije istupa iz izvornoga stanja neznanja i postaje onim znajućim. Potom prolazi kroz sve moguće forme znanja odnosno pojedine momente totalnoga sistema. Dok je u stanju mirovanja, dotle je u stanju neznanja, i tek prelazeći u stanje znanja on započinje svoje navlastito kretanje prema kraju kao ponovno uspostavljenom početku.

30

F. W. J. Schelling, IPU, str. 22.

31

Igor Mikecin, »Sloboda i sistem«, u: Damir Barbarić (ur.), Sloboda i zlo: Schellingov "Spis o slobodi«, Matica hrvatska, Zagreb 2017., str. 29-41, str. 39.

32

F. W. J. Schelling, IPU, str. 7.
33

Ibid., str. 18 .

34

F. W. J. Schelling, IPU, str. 22; F. W. J. Schelling, SW I/9, str. 221.

35

F. W. J. Schelling, IPU, str. 23. 
»Ne može se znati što je apsolutni početak; on prestaje biti početkom prelazeći u znanje i zato mora napredovati dok se opet ne pronađe kao početak. Ponovno uspostavljeni početak, kao samoga sebe znajući početak, kraj je svega znanja. ${ }^{36}$

Uspostavljanje znanosti zapravo je uspostavljanje sistema znanosti.

»To se može desiti samo putem odjeljivanja, dakle putem znanosti i dijalektike, za koje vjerujemo da će jedino one biti te koje će onaj sistem koji je češće, nego što mislimo, bio tu, ali je uvijek iznova prohujao, koji nam svima lebdi pred očima i koji još nitko nije sasvim obuhvatio, zadržati i zauvijek privesti k spoznaji. « ${ }^{37}$

Postati znajući i svjestan one vječne slobode zapravo je pitanje koje pretpostavlja još jedno drugo i temeljnije, a to je kako uopće vječna sloboda može biti spoznata. Da bi sama vječna sloboda mogla biti spoznatljiva i utoliko postati spoznata mora se nužno upasti u proturječje. Naime, vječna sloboda kao apsolutni subjekt u apsolutnom je prastanju i ona kao subjekt ne može nikada postati objekt, a postojanje objekta pretpostavka je svakoga znanja koje se mora spram nečega takvoga kao što je objekt odnositi. Apsolutni subjekt Schelling označava kao ono naprosto transcendentno.

Iako je evidentno kako apsolutni subjekt nikada ne može do kraja biti predmetan jer je predmetnost kao takva za njega nemoguće stanje, ipak prema Schellingu nije nemoguće da bi on nekako mogao postati objekt odnosno predmet. Opredmećenje apsolutnoga subjekta odnosno vječne slobode uistinu je moguće.

»Budući da je ona apsolutna sloboda, tj. sloboda i da ne bude sloboda (ne bude subjekt), ona može istupiti kao subjekt. Ona se dakako tada dade znati kao objekt, vidimo ju u svim njenim obličjima, ali ne kao vječnu slobodu, ne kao subjekt, ne kako je ona po sebi.«38

Sada je pak problem da je ona spoznatljiva, ali ne kao vječna sloboda, nego samo kao nešto drugo od nje same. Dakle, opet nije spoznatljiva po sebi.

»Kao apsolutni subjekt ona je iznad svake spoznaje, kao objekt ona nije u svojem po-sebi.«39

Prema tome, postoji samo jedan način na koji bi apsolutni subjekt kao takav mogao biti spoznat. Takav oblik spoznavanja ima svoj uvjet mogućnosti u tome da bude kao subjekt ponovno uspostavljen iz objekta, jer tada nije više samo subjekt, a ipak nije više ni samo objekt, nego je kao objekt ujedno i subjekt, a kao subjekt ujedno i objekt. To je uistinu ispunjenje najvišeg i najarhaičnijeg principa spoznavanja prema kojemu ono spoznavajuće mora biti ujedno i spoznato, a ono spoznato ujedno i ono spoznavajuće. Takav aksiom spoznavanja navodno potječe još od Pitagore, no susreće se i kod Platona, a jasno ga izriče Empedoklo. ${ }^{40}$ Dakle, mogućnost samospoznaje za apsolutni subjekt leži u jednoj preobrazbi odnosno metamorfozi. Apsolutni subjekt ne može spoznavati samoga sebe na početku jer je tada čisto odnosno mirujuće znanje koje je ujedno ne znajuće znanje. Usred kretanja kroz momente sistema apsolutni subjekt ne može sebe spoznavati kao vječnu slobodu, ali zna se kao nešto drugo od sama sebe.

»[S]amo je na kraju on sebe spoznavajući kao on sam.«41

Budući da ne postoji ništa što bi bilo izvan ili mimo apsolutnoga subjekta kao vječne slobode, uistinu za njega ne može biti nikakvoga drugoga predmeta spoznavanja doli njega samoga. Spoznaja je proces u kojem se subjekt i objekt poistovjećuju. Vječna sloboda, kako bi spoznavanje uopće bilo omogućeno, nužno mora biti razdijeljena na dva pola, na subjekt i na objekt. Ti se polovi, kao uvjeti čitavoga kretanja, nikada ne smiju slučiti, nego moraju 
biti držani odvojenima. U suprotnom, kad bi se takvi polovi susreli, smjesta bi nestalo kretanja.

»Može se to pojasniti magnetnom iglom: kada bi se oba pola u magnetnoj igli mogla sastati, prestao bi njen život.«42

Svrha znanosti jest ponovno dovesti čovjeka do znanja da je nekada uistinu bio središte svega, odnosno da je bio apsolutni subjekt kao vječna sloboda.

»Kao znanost i ukoliko je znanost filozofija je znanost apsolutnog subjekta.«43

Na kraju procesa vraćanja vječne slobode samoj sebi ni apsolutni se subjekt ne može više shvaćati kao ono samo ne znajuće, a ni čovječja svijest nije više znanje zato što joj nedostaje objekt znanja. Na kraju pojedinačna svijest postaje svjesna sebe kao ono što je mirno nutarnje apsolutnog subjekta i predstavlja njegovo znanje, dobiveno prolaskom kroz sve moguće momente vječne slobode, jer ga je vratila njemu povratkom u iskonsko i slobodno jedinstvo s njim. Slobodno mišljenje spoznalo je vječnu slobodu i uvidjelo da je njen subjekt, a ujedno je i spoznalo sama sebe jer je prošlo sve svoje dubine.

»Ali upravo je to trebalo biti postignuto, da ono samoga sebe zna kao ono nutarnje vječne slobode. Bilo je ono prije nutarnje vječne slobode, ali ne znajući. - Dakle, cilj je neposredno znanje vječne slobode. $\ll^{44}$

\section{Nužna proturječja filozofije kao znanosti}

Da bi to sve prethodno opisano znanost kao znanost mogla, ona mora krenuti od svoga izvora, odnosno izvora svega što uopće jest, a to je vječna sloboda. Ali da bi znanost od nje mogla krenuti, ona mora za nju znati, a kakva bi onda znanost uopće bila potrebna ako se već otpočetka zna što čovjek kao čovjek jest, a što vječna sloboda sama jest. Schelling uviđa kako je to proturječje u obliku očitoga kruga iz kojega naizgled nema izlaza.

»Morali bismo već imati rezultat znanosti, da bismo mogli tek započeti znanost. « ${ }^{45}$

Schelling moguće razrješavanje te velike teškoće u koju je istraživanje upalo pokušava govoreći o možebitnoj u čovjeku postojećoj i samo njemu pripadnoj moći slućenja (ahnen), ali ono se ubrzo pokazuje kao nesavršeno znanje jer se odnosi tek na ono buduće, na ono što ima doći.

36

F. W. J. Schelling, IPU, str. 25; F. W. J. Schelling, SW I/9, str. 222-223.

37

F. W. J. Schelling, Filozofijska istraživanja o bitstvu čovječje slobode, str. 65.

38

F. W. J. Schelling, IPU, str. 30; F. W. J. Schelling, SW I/9, str. 225.

39

F. W. J. Schelling, IPU, str. 30; F. W. J. Schelling, SW I/9, str. 226.

40

Usp. F. W. J. Schelling, Filozofijska istraživanja o bitstvu čovječje slobode, str. 17.
41

F. W. J. Schelling, IPU, str. 31; F. W. J. Schelling, SW I/9, str. 226

42

Ibid.

43

Branko Despot, »Mišljenje slobode «, Filozofska istraživanja 8 (1988) 1, str. 3-7, str. 4.

44

F. W. J. Schelling, IPU, str. 57; F. W. J. Schelling, SW I/9, str. 240.

45

F. W. J. Schelling, IPU, str. 36; F. W. J. Schelling, SW I/9, str. 228. 
»Doduše, ne može se sada proturječiti, da mi s prvim korakom u filozofiju slutimo također i kraj, da nema znanosti bez divinacije. Ali nije jednako diviniram li na početku kraj ili pak slutim sam početak, zato što je potonje proturječje. ${ }^{46}$

Razlika između početka i slutnje mora se održati.

»Početak ukazuje na sadašnjicu, slućenje na budućnost. $\ll^{47}$

Isti je slučaj i ako se pokuša krenuti s vjerovanjem kao jednom od specifičnosti pripadnih čovjeku. Ali vjerovati u princip i to na temelju istoga principa nije moguće i ne pruža dovoljno sigurnosti ni izvjesnosti u istraživanju razvoja i svrhe znanosti. Ljudi koji žele u filozofiju ući vjerovanjem na način da odbacuju znanje skončavaju, prema Schellingu, zapravo na putu filozofijskoga nevjerovanja. Naime, iz upotrebe termina vjerovanja i znanja jasno je kako vjerovanje nije suprotstavljeno znanju, nego gledanju odnosno zrenju. Schelling navodi novozavjetni izrijek: »Blaženi koji ne vidješe, a vjeruju! 48 Tako je vjerovanje određeno kao uvjerenost u držanju nečega mogućim, ali ne neposredno, nego kroz moguće povezivanje svih okolnosti. Vjerovanje nikada ne smije pretpostavljati cilj koji ne bi bio dostižan, a ujedno mora imati i karakter djelatnosti.

»Kazati: ‘ja vjerujem', a pritom ništa ne učiniti, neposredno je proturječje. Dakle, ono vjerovanje je zapravo nevjerovanje. Sva znanost kao takva, koja prolazi kroz jedan srednji član sve do posljednjega, rođena je vjerovanjem. $\ll^{49}$

Prethodno spomenuta teškoća ne može se razriješiti ni uvođenjem mogućnosti postavljanja hipoteze s kojom bi se započelo, a koja bi svoju izvjesnost stekla tek na samom kraju potvrđujući se kao valjana. Problem je s hipotezom u tome što bi tu čovjek bio uvijek onaj koji tu hipotezu postavlja, a s njom i samu znanost.

»Ali u filozofiji vrijedi, da se mora uzdignuti iznad svega znanja, koje puko potječe od mene. $\ll^{50}$

Na jednom drugom mjestu u Dobima svijeta Schelling slično kazuje:

»Dosad važeća predodžba o znanosti bijaše da je ona puki slijed i razvoj vlastitih pojmova i misli. Istinska je predodžba da ono što se u njoj prikazuje jest razvoj živog, zbiljskog bitstva. $\ll^{51}$

Kao ni prethodno spomenute postavke u sistemu, tako ni hipoteze ne mogu biti početak ili svrha filozofije zato što, prema Schellingu, filozofija uopće nije neka demonstrativna znanost koja bi podrazumijevala da se smjesta kreće od nečega poznatoga prema nečemu drugome isto takvom sve do kraja kao najizvjesnije spoznatosti i znanja o nečemu. Ta kriva predodžba, koju Schelling označava kao glavnu zabludu (Hauptirrthum), uzrok je tomu da većina ljudi nikada ne uđe u istinsku filozofiju i filozofiranje jer misle da imaju posla s demonstrativnom znanošću, pa kad uvide da tomu nije tako, njihovo je razočaranje golemo.

»Ali filozofija nije demonstrativna znanost, filozofija je, da se u nekoliko riječi iskaže, slobodan čin duha; njen prvi korak nije znanje, nego štoviše izričito neznanje, napuštanje svega znanja za čovjeka. «52

Sve dok čovjek u svom znanju hoće znati, reducirat će apsolutni subjekt na status pukoga objekta i tako će ga uistinu spoznati, ali kao objekt, a ne kao apsolutni subjekt po sebi.

»Početak sve znanosti leži u spoznaji njegova neznanja; ali nemoguće je da čovjek sebe sama postavi kao ne znajućega a da time znanost sebi iznutra ne učini predmetom svoje žudnje. $\ll^{53}$ 


\section{Ekstaza kao istinski odnos prema apsolutnom subjektu}

Čovjek može biti svjestan apsolutnog subjekta samo u slučaju kada ga ne čini objektom vlastitoga htijenja za znanjem. Kada se apsolutni subjekt pretvori u puki predmet, tada ga se doduše može znati, ali nikada kao uistinu apsolutni subjekt. Upravo je zato temelj i početak filozofije izričito neznanje, odnosno odricanje od znanja kako bi se apsolutni subjekt spoznao kao subjekt, a ne kao objekt. To je čovjeku jedini otvoreni put za ulazak u filozofiju.

»Time što on kaže: ja, kao ja, ne mogu znati, ja - hoću ne znati, time što se On odriče znanja, stvara on prostor za ono što je znanje, naime za apsolutni subjekt, o kojem je pokazano da je upravo znanje samo. U tom aktu, budući da on samoga sebe odlučuje za neznanje, on upravo postavlja apsolutni subjekt $k a o$ znanje. $\ll^{54}$

Uistinu, takav akt ne prethodi i ne zbiva se jedino u prvom čovjeku, nego u svakom. Taj proces i odnos čovjeka spram apsolutnog subjekta Schelling pokazuje kao odlučujući moment svoje filozofije. Takav se odnos, odnosno takvo ne znajuće znanje, u tradiciji njemačkog idealizma imenovalo intelektualnim zorom jer se držalo kako se subjekt zrenja gubi i sama sebe zaboravlja u aktu zrenja. Takav je zor intelektualan jer tu subjekt ne zre uz pomoć osjetilnoga zrenja, što bi ipak značilo da je subjekt zrenja kao subjekt izgubljen prešavši u oblast objektiviteta, nego se time označava da je subjekt izgubljen na način sebedavanja i sebenapuštanja u onome što nikako ne može biti objekt.

»Intelektualni zor, u kojem se apsolutno zrije kao jedinstvo, postaje onda apsolutno znanje, a refleksivno mu se podredjuje; jednako postaje ono apsolutno osnov bitku duha i tvari, duh i tvar očitovanja njegova, a filozofija je nauka o apsolutnome. $\ll^{55}$

Intelektualni zor čovječjega uma osigurava identitet prirode i duha. Takav je zor uistinu izvor znanja jer nitko ne može ugledati istinu osim onoga koji ju je već gledao u vječnosti.

»Istina je samo u apsolutnom znanju, u jednom znanju koje bi bilo u Bogu i iz Boga. Pojam intelektualnog zora potječe od Fichtea. Stvar je pak starija i kod Schellinga intelektualni zor ponovno stoji bliže metafizičkoj tradiciji philosophia perennis nego kod Fichtea, gdje je on još bio subjektivistički onečišćen, premda je također i tamo zadatak, koji je on trebao ispuniti, bio star: utemeljenje znanosti i prve filozofije. $\ll^{56}$

Schelling poduzima i kritiku onih koji se nazivaju teozofima jer smatraju da je čovjeku dovoljno stajati u stanju neposrednoga zrenja i žele sve imati na taj način, no upravo je to u filozofiji jedna stranputica. Ako filozofija hoće posta-

46

F. W. J. Schelling, IPU, str. 36-37; F. W. J. Schelling, SW I/9, str. 228.

47

F. W. J. Schelling, IPU, str. 37.

48

Iv 20,29.

49

F. W. J. Schelling, IPU, str. 58.

50

F. W. J. Schelling, IPU, str. 37; F. W. J. Schelling, SW I/9, str. 228.

51

F. W. J. Schelling, Dobā svijeta, str. 7.
52

F. W. J. Schelling, IPU, str. 38; F. W. J. Schelling, SW I/9, str. 228.

53

F. W. J. Schelling, Dobā svijeta, str. 31.

54

F. W. J. Schelling, IPU, str. 38; F. W. J. Schelling, SW I/9, str. 229.

55

Albert Bazala, Povijest filozofije, sv. 3, Povijest filozofije najnovijega doba, Matica hrvatska, Zagreb 1912., str. 88.

56

J. Hirschberger, Geschichte der Philosophie, str. 387. 
ti znanost, onda uistinu mora u sebi imati zadržavajući princip spram onoga apsolutnog subjekta. Zrenje mora dobiti vlastito primjereno vrednovanje jer ono ima svrhu i smisao, ali njome svrha same filozofije neće i ne može biti dostignuta.

»Čovjek je mogao onaj slijed procesa zacijelo nutarnje iskusiti, ali sve iskušeno, osjećano i zreto nijemo je. Stoga se potrebuje jedan posredujući, izražavajući organ. «77

Upravo je zato znanost primjeren oblik dohvaćanja istine u sistemu kao cjelini svega što jest.

»U teozofijskim sistemima često je doduše jedno izobilje života; ali to također nije strano ni mirnom ispitivanju, ono samo sporije to dostiže. $\ll^{58}$

Teozofija se može spram filozofije doista činiti životnijom, bogatijom sadržajem i dubljom, kao što je to i priroda spram njenoga pukog prikaza ili zbiljski predmet spram svoje slike, ali za Schellinga se samo postupno može roditi nešto takvo kao što je znanost.

»Ali kao što je priroda nedohvatljiva ispravno razumljenoj umjetnosti, tako je i punina i dubina života nedohvatljiva ispravno razumljenoj znanosti; samo postupno, posredno i stupnjevitim napredovanjem ona dospijeva do nje, tako da znalac uvijek ostaje različit od svoga predmeta, naspram čega i ovaj ostaje odvojen od njega i biva objektom jednog razboritog, mirno uživajućeg motrenja. «59

Da bi se filozofija utemeljila kao znanost, potrebno je prikazati zašto i odakle potječe njena nužnost. Schelling je to učinio opisivanjem neizbježnog i nerazrješivog nutarnjeg proturječja u samom znanju. Takav je spor neizbježan jer svijest čovjeka ne može nikada ostati stajati u stanju onoga mirnog nutarnjeg ili nosećeg vječne slobode kao pokretljivosti same. Čovjek tu vječnu slobodu, koja on ustvari i jest, želi znati i time je zapravo pretvoriti u predmet, u objekt, ali to se ne događa pod bilo kakvom prisilom, no događa se upravo nužno i neizostavno. Cilj njegove težnje i htijenja takve vječne slobode zapravo leži $\mathrm{u}$ tome da on s njom hoće postupati samovoljno. To htijenje nije bilo prisutno samo na početku nego je upravo vidljivo u svakom pojedinačnom čovjeku.

»Svaka je pojedinačna čovječja svijest ponovno neko dolaženje k sebi vječne slobode. Ali u svakoj se čovječjoj svijesti događa ponovno isto privlačenje. $\ll^{60}$

Tako čovjek preokreće i preobraća istinski poredak slobode.

»Čovjek kao apsolutno Ja ili apsolutno sebstvo time porobljuje slobodu samu čineći je svojom slobodom. Gledano iz vječne slobode, to je porobljavanje slobode onim koje sloboda može biti ali sloboda nije, te je, kao apsolutiziranje Ne-slobode, samouspostavljeno, slobodu kao sredstvo imajuće robovanje. $\ll^{61}$

Schelling posebno naglašava kako izraz »intelektualni zor« nije primjeren njegovoj potrazi za istinskom znanošću jer je težak za shvaćanje, a ujedno iziskuje daljnje razvijanje i objašnjavanje. Ono pak što se u tom trenutku može koristiti svakako jest pojam ekstaze. U ekstazi čovjekovo Ja biva postavljeno izvan samoga sebe, odnosno postavljeno je izvan sebi naizgled primjerenog mjesta, a to je biti subjektom. Čovjekovo Ja ne može nikada odmjeravajući se spram apsolutnog subjekta i samo biti subjekt, nego mora postati objekt. ${ }^{62}$ Prema Schellingu, upravo je takvo zbivanje sebenapuštenosti Platon u svom Teetetu opisivao kao iskonsku udivljenost (Erstaunen) i kao afekt svojstven filozofima u filozofiranju.

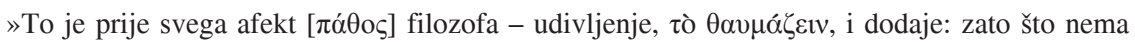
nikakva drugog početka filozofije od udivljenja. « ${ }^{63}$ 
Schelling smatra potrebnim istaknuti i jedno upozorenje početnicima u filozofiji. Naime, oni se često mogu susresti s ljudima koji im ne čine dobro pozivajući ih da uvijek zalaze što više u svoju nutarnjost, u svoju navodno najdublju dubinu, ali time ih zapravo pozivaju neka se upuste jedino u vlastitu ograničenost, dok je čovjeku gotovo kao nužnost dan imperativ da u ekstazi bude postavljen izvan sebe samoga.

»Biti postavljen izvan sebe i sebe ot-pustiti, jest put prema istini. $\ll^{64}$

Time što čovjek izlazi iz samoga sebe, može tek uistinu ponovno svjesno i sa znanjem doći do onoga što je on bio i što bi on ponovno trebao postati. Čovjeku preostaje jedino otpustiti samoga sebe kao subjekt kako bi njegovo znanje moglo biti uzdignuto.

»Naime, bio je On vječna sloboda, koja je samu sebe izgubila, koja se ponovno tražila kroz čitavu prirodu - on je ponovno bio ta k samoj sebi dovedena sloboda, i trebao je kao ta, dakle, i ostati; ali time što se samo ponovno htio ogledati u njoj, nju dokučiti, nju privući sebi, dakle dok je htio sebe činiti subjektom, dotle je dakako ostajao subjekt, ali mu je sada i vječna sloboda ostajala pukim objektom. ${ }^{65}$

Pod ekstazom valja razumjeti bilo kakvo udaljavanje ili otpuštanje s nekoga mjesta. Budući da je tomu tako, ekstaza sama po sebi nije nešto što bi se trebalo shvaćati isključivo jednoznačno i u pozitivnom smislu. Ona može biti i vrlo negativna kada, prema Schellingu, označava udaljavanje nekoga s njemu prikladnoga ili doličnoga mjesta. Tada je ekstaza uistinu ta koja dovodi čovjeka do besmisla. Ekstaza može biti uzeta i u spasonosnom smislu kada označava udaljavanje s nekoga čovjeku neprimjerenog ili nedoličnog mjesta. U tom je slučaju ekstaza spasonosnoga karaktera, a kao svoju najizravniju i neposrednu posljedicu ima dovođenje čovjeka do razine svjesnosti odnosno prisebnosti. Čovjek do takve spasonosne ekstaze može biti doveden određenim postupcima, a takvo dovođenje čovjeka do ekstaze prispodobivo je dovođenju čovjeka do prisebnosti. ${ }^{66}$

Većina se ljudi po svojoj naravi nalazi u stanju neprisebnosti. To je stanje koje čovjeka nije dovelo čak ni do one najviše moguće točke napetosti kada neka odluka postaje nužna kako bi se ta napetost razriješila. Da bi do odluke moglo doći, potrebna je velika nutarnja duhovna djelatnost, ali većina ljudi ipak odustaje prijevremeno od toga i povlači se u stanje omamljenosti koje im se doima ugodnim jer na taj način izbjegavaju odluku.

»Tako se događa da u većini ona nutarnja borba ne dospijeva do izbijanja, ili barem ne dospijeva do onog stupnja napetosti, koja odluku čini nužnom. $\ll^{67}$

57

F. W. J. Schelling, IPU, str. 59.

58

Ibid.

59

F. W. J. Schelling, Dobā svijeta, str. 12.

60

F. W. J. Schelling, IPU, str. 60; F. W. J. Schelling, SW I/9, str. 240.

61

B. Despot, »Mišljenje slobode«, str. 5-6.

62

Usp. F. W. J. Schelling, IPU, str. 39; usp. F. W. J. Schelling, SW I/9, str. 229.
63

Ibid.

64

F. W. J. Schelling, IPU, str. 40.

65

F. W. J. Schelling, IPU, str. 40; F. W. J. Schelling, SW I/9, str. 230.

66

Usp. F. W. J. Schelling, IPU, str. 41; usp. F. W. J. Schelling, SW I/9, str. 230. Uistinu, u hrvatskom se jeziku to ogleda kao stanje onoga pri-sebi-biti odnosno biti priseban.

67

F. W. J. Schelling, IPU, str. 61; F. W. J. Schelling, SW I/9, str. 241. 
Čin odluke nužan je za čovjeka. Odluka ipak nije jednom zauvijek gotov čin, nego se uvijek iznova ima ponavljati. Od-lučivanje i lučenje ne smije nikada prestati da bi uopće moglo biti bića. ${ }^{68}$

»Čin, kojim je određen njegov život u vremenu sam ne pripada vremenu, nego vječnosti: on niti životu ne prethodi po vremenu, nego hodi kroz vrijeme (nezahvaćen od njega) skroz kao jedan po prirodi vječan čin. $\ll^{69}$

Taj nutarnji spor u svakom čovjeku postoji upravo po njegovoj naravi, a ne uzgredno. Schelling time nastoji objasniti fenomen izvan oblasti tzv. školske filozofije. Naime, u svakom se vremenu pojavljuje nekoliko neukih i nepoučenih ljudi koji, čini se bez bilo kakve formalne naobrazbe, »filozofiraju na svoj način « ${ }^{70}$ usprkos žestokim protivljenjima učenjaka i profesora filozofije. Oni su ti koji izdržavaju u krizi i času donošenja odluke.

»Gdje je pak onaj nutarnji spor izvorno pobuđen, a da se nije razriješio u prisebno znanje kroz onu krizu i lučbu, tamo on nužno rađa ono što mi imenujemo zabludama, a sve su zablude samo tvorevine onih nutarnjih, u surovoj borbi međusobno se borećih duhovnih snaga. «11

Čovjek u ekstazi, u stanju posvemašnjega neznanja, jer je u stanju napuštenosti od svega znanja, pokazuje se kao onaj koji postavlja apsolutni subjekt. Apsolutni subjekt tako je onaj koji ne zna vlastitoga postavljača, naime čovjeka, a čovjek je ujedno onaj koji ne zna da je apsolutni subjekt rezultat njegova postavljanja. Upravo to prvotno postavljanje apsolutnoga subjekta može se prispodobiti i svakom pojedinačnom znanju. Naime, svako je znanje u stanju postojane promjene jer je uvijek jedno te isto, a zapravo stalno neko drugo. To je upravo ono najsvojstvenije i istinsko bitstvo znanja. Apsolutni subjekt otkriva se kao praslika našega znanja. Schelling upozorava na to da tu ne treba razumijevati aktivno i svojevoljno preoblikovanje našega znanja, nego tek pasivno bivanje preobraženim. Svako pojedinačno obličje takvoga znanja je ono obrnuto, ono reflektirano kao refleks znanja u vječnoj slobodi. Zato čovjek može u sebi apercipirati svaku promjenu obličja jer svaku takvu promjenu može reflektirano neposredno spoznati u samom sebi. Svaka promjena u apsolutnom subjektu ima u čovjekovoj nutarnjosti analogon samoj sebi. Naime, apsolutni subjekt je čovjekov duh u velikom, a čovjekov duh je apsolutni subjekt u malom.

»Mi nismo samo dokoni promatrači nego smo sami u jednoj postojanoj preobrazbi sve do obličja potpune spoznaje; nije to nikakav površni proces, to je jedan dubokozadirući proces, koji zaorava brazde svoga kretanja u našu vlastitu nutarnjost. I to tako mora biti. Ništa puko izvanjsko ne može biti dovedeno ljudima. Nutarnjom lučbom i oslobođenjem mora se do nas uzdignuti svjetlo znanosti.«72

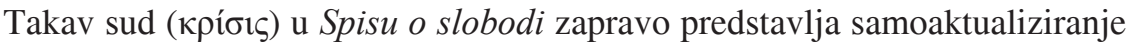
Boga.

»Bog žrtvuje ideje koje su u njemu bile bez samostalnog života, u samost i ono nebitstvujuće, da bi one, time što se iz ovoga dozivaju u život, kao neovisno egzistirajuće bile ponovno $u$ njemu. $\ll^{73}$

Schelling je u tom kontekstu poduzeo i kratko, ali ozbiljno razmatranje odnosa između filozofijskoga i historijskoga znanja. Historijskom znanju svojstveno je mrtvilo koje se izražava kroz puko shvaćanje historijskih činjenica, ali ono što krasi filozofijsko znanje jest prije svega mogućnost dokazivanja i pokazivanja pojedinačnih momenata i čitavoga kretanja vječne slobode kao prirode. Prema Schellingu, povijest prirode ostavila je za sobom brojne spomenike na 
svim momentima i stupnjevima svoga prolaska i razvoja. Prirodna znanost odgonetnula je veliku većinu takvih spomenika i mnogi od njih čovjeku više nisu nikakva tajna, ali i dalje su svi ti spomenici naprosto ostali nijemi. Ostali su nijemi jer istinsko znanje može biti postignuto samo nutarnjim duhovnim razvojem. ${ }^{74}$

Upravo zato treba razlikovati filozofiju od historije (pri-povijesti) jer stvorena cjelina kao niz vječnih preoblikovanja i metamorfoza ne može biti ispripovijedana niti pojmljena kroz priče, što je svojstveno historijskoj znanosti koja svoj temeljni predmet (povijest) iznosi u formi pri-povijesti. Čak i u slučaju da nekako ima kronike svih mogućih događaja i da ima duhovnih sposobnosti njenoga čitanja, ako bi se takva znanja prenosila tek poput niza priča povezanih apriornim zakonom kauzaliteta, to bi značilo ništa drugo doli mrtvo historijsko znanje. Filozofija je pak u najužoj vezi s predmetom historije, odnosno s poviješću duhovnoga života jer je to jedno jedino što jest pa stoga ne treba čuditi interes filozofije i historije za njima zajednički predmet - povijest.

»Zato sva objava hoće biti [također] samo poticaj ili sredstvo razvoja za čovječji rod. Objavi zapravo pristoji dijeliti taj izvještaj, ali ona se suzdržava od njega. Naprotiv, govori više u poredbama i mračnim riječima. (...) Ona ne bi htjela vlastite napore čovjeka učiniti uzaludnima. Ona je računala na to i pretpostavljala ga je. Sve, što treba čovjeku biti razumljivo, mora doći iz same njegove nutarnje dubine. « ${ }^{75}$

Schellingova namjera, kao što je vidljivo iz njegovih riječi, ali i iz samoga tijeka srednjega razdoblja njegove filozofije, nije pokazati čitavu nutarnju genezu opisanoga procesa odnosno filozofije. To bi podrazumijevalo detaljan opis tijeka i hoda nutarnjega razvoja samoga čovjeka, ali filozofija ne smije izlagati svoje rezultate, nego samo put do njih.

»Filozofija kao (čovječja težnja) subjektivno znanje čovjeka leži kao određeni moment, kao sveopća točka razvoja i linija napredovanja u samom čovjeku. «76

Treba stoga imati u vidu kako je sve ovdje od Schellinga dano tek u općim crtama, a ne u pojedinačnim detaljnim izvedbama čitavoga kretanja apsolutnog subjekta kao vječne slobode. Prema Schellingu, dani i opisani odnosi između apsolutnoga subjekta i znanja predstavljaju nacrt jedne teorije filozofije. $^{77}$

68

Usp. Damir Barbarić, »Schellingova 'genealogija vremena' «, Filozofska istraživanja 8 (1988) 1, str. 27-37, str. 34.

69

F. W. J. Schelling, Filozofijska istraživanja o bitstvu čovječje slobode, str. 47-48.

70

Usp. F. W. J. Schelling, IPU, str. 60.

71

F. W. J. Schelling, IPU, str. 61; F. W. J. Schelling, SW I/9, str. 241.

72

F. W. J. Schelling, IPU, str. 48; F. W. J. Schelling, SW I/9, str. 234.
73

F. W. J. Schelling, Filozofijska istraživanja o bitstvu čovječje slobode, str. 59.

74

Usp. F. W. J. Schelling, IPU, str. 48.

75

Ibid., str. 49.

76

Ibid., str. 41.

77

Usp. ibid., str. 46. 


\section{Um kao prasvijest}

Univerzalna svijest (apsolutni subjekt) i partikularna svijest (znanje pojedinačnoga čovjeka u stanju neznanja) samo su prasvijest koja ponovno nastoji uspostaviti samu sebe. Iako prasvijesti više zbiljski nema, ona još uvijek postoji u mogućnosti i može ponovno biti uspostavljena. Takvu ponovno uspostavljivu prasvijest, koja se trenutno nalazi samo u klici, Schelling imenuje umom.

»Sama ta prasvijest u svojem je potencijalitetu, u svojoj pukoj uspostavljivosti um, ili još određenije: prasvijest, koja u onoj međusobnoj odvojenosti teži sebe ponovno uspostaviti, koju u nama osjećamo samo kao neki poticaj, kao neki poziv, kao neko povlačenje, jest um. «78

Schelling time jasno pokazuje da um nikada ne može biti bilo kakav djelatni princip u znanosti zbog sebi inherentne, potencijalne, uvijek samo trpeće naravi.

»On nije djelatnost, kao duh, nije apsolutni identitet obaju principa spoznaje, nego je indiferencija; mjera i tako reći opće mjesto istine, mirno stanište, u kojem se prima izvorna mudrost, po kojoj, gledajući je kao uzor, razum ima obrazovati. Filozofija ima svoje ime s jedne strane od ljubavi, kao opće nadahnjujućeg principa, s druge strane od ove izvorne mudrosti, koja joj je pravi cilj. $\ll^{79}$

Čovjekovo ne znajuce i zbog toga slobodno mišljenje korelat je apsolutnomu subjektu s obzirom na to da su oboje izbačeni iz prasvijesti. Ta je prasvijest ujedno po vlastitoj biti svijest svakoga pojedinačnog čovjeka i upravo zato čovjekovo slobodno mišljenje jest to koje postavlja apsolutni subjekt. Kada se kaže da je svijest pojedinačnoga samo osnova svijesti vječne slobode same, odnosno da je čovječja svijest ona k samoj sebi došla sloboda i da je njen subjekt, onda tu treba razjasniti prvo sam pojam kopule. Prema Schellingu, kopula može biti pojmljena kao copula verbalis ili kao copula realis. Verbalna ili puka kopula bila bi ono »jest « u rečenici: »U krugu jest jedan krug.« Pojam pak realne kopule, koju treba razumijevati u onome što je rečeno o odnosu apsolutnog subjekta kao vječne slobode i svijesti pojedinačnoga, vidljiv je u rečenici: »Taj određeni željezni prsten jest krug.«

»Tamo to jest ima značenje biti subjekt, biti podmetnuto. Taj prsten jest subjekt kruga, nije krug sam. $\ll^{80}$

Upravo tako treba razumijevati i pojedinačnu svijest kao subjekt ili ono podmetnuto univerzalne svijesti apsolutnog subjekta kao vječne slobode, a da ipak ta svijest nije vječna sloboda sama.

U svom Spisu o slobodi Schelling je već pojasnio pojam kopule jer je njeno pogrešno poimanje u filozofiji dovelo do najgorih zabluda i neispravnih mnijenja. Naime, identitet subjekta i predikata povezan kopulom ni u kojem smislu ne uključuje jednoobraznost, odnosno ukratko rečeno, jednakost ne podrazumijeva jedinstvo. Upravo tamo gdje se govori o jedinstvu, nema mjesta govoru o jednakosti. Identitet subjekta i predikata hoće reći samo to kako predikat jest kroz subjekt, a ne kroz nešto o njemu neovisno ili kroz samoga sebe. U tom smislu čak ni tautologija ni najmanje ne pretpostavlja nekakvu jednakost subjekta i predikata kao da bi se radilo o istovjetnosti. Logika, koja još uvijek ima dovoljno uvida u ono logičko, razlikovala je prethodeće i slijedeće (antecedens et consequens). Schelling daje još jedno starije i dublje objašnjenje kopule od toga, a odnosi se na poimanje suprotstavljenosti subjekta i predikata kao onoga uvijenoga i razvijenoga (implicitum et explicitum). ${ }^{81} \mathrm{U}$ Dobima svijeta Schelling podrobnije kazuje: 
»Dalje, to da je u jednostavnom pojmu sud već unaprijed oblikovan, a u sudu već sadržan zaključak, te je stoga pojam samo uvijeni, a zaključak razvijeni sud, zamjedbe su koje se ovdje polažu za jednu buduću najpoželjniju razradu plemenitog umijeća uma $(\ldots.) . \ll^{82}$

Schelling pravi važnu ogradu od mogućega pogrešnoga razumijevanja upravo rečenoga kada kaže da je apsolutni subjekt misao čovjeka, ali ne na način ili u smislu u kojem bi neka himera bila misao čovjeka. Apsolutni subjekt takva misao naprosto ne može biti jer je pojam sam, a nije predmet čovjekovog pojma. Apsolutni subjekt nikada ne može postati objektom i u tom je smislu nepredmetan odnosno neobjektan. Također, apsolutni subjekt kao pojam nije puki pojam, nego vječna sloboda sama imenovana pojmom isključivo iz razloga što može izvorno i iskonski biti pojmljena u prasvijesti, koja je bila i naša svijest.

»Znanje je staro koliko i univerzum; ono je s njim istodobno rođeno, a nije mu tek pridošlo. $\ll^{83}$

Dakle, mišljenje uopće vremenski ne prethodi takvom aktu postavljanja apsolutnog subjekta, jer u tom se trenutku još uopće ne može govoriti o vremenu, nego pojavljivanje apsolutnog subjekta i slobodnog mišljenja iz stanja prasvijesti valja misliti istodobno $\mathrm{i}$ istovremeno. Odnos kakav vlada između mišljenja i apsolutnog subjekta, analogan je u tom smislu odnosu temelja egzistencije u Bogu i samoga Boga.

»Što se inače tiče onoga prethođenja, to njega ne valja misliti niti kao prethođenje po vremenu, niti kao prioritet bitstva. U krugu iz kojega sve biva nije nikakovo proturječje, da ono kroz što se jedno proizvodi, sâmo bude opet proizvedeno od njega. ${ }^{84}$

Takav je događaj uistinu jedinstven. Početak filozofije jest najviši trenutak zbivanja krize što za posljedicu ima rođenje slobodnoga mišljenja. To je istinska ljubav prema mudrosti. ${ }^{85}$

»Slobodno mišljenje, koje se odupire svem znanju, vidi se sada nasuprot apsolutnom subjektu. To je veliki moment, pravi sat rođenja filozofije. $\ll^{86}$

Potrebno je ipak pobliže odrediti sam pojam mišljenja. Mišljenje je oduvijek važilo kao upravo jedini filozofiji primjeren instrument ili organon filozofiranja. Upravo je po mišljenju čovjek odvojen od okolnoga svijeta koji mu stoji samo kao objekt mišljenja, dok ono misleće u mišljenju misli ono mislivo u objektivitetu spram sebe kao subjekta. Mišljenje već pretpostavlja razdvoj odnosno dualizam subjekta i objekta. Tu se razotkriva pozitivna narav mišljenja vezana uz ono bitstveno i sadržajno, ali otkriva se i negativna slika mišljenja koja odvaja biće od bića i pretvara ga u misaoni pojam, koji nije ništa drugo doli čista negativna paslika onoga mislivoga. ${ }^{87}$

78

F. W. J. Schelling, IPU, str. 53; Schelling, SW I/9, str. 236.

79

F. W. J. Schelling, Filozofijska istraživanja o bitstvu čovječje slobode, str. 66.

80

F. W. J. Schelling, IPU, str. 50.

81

Usp. F. W. J. Schelling, Filozofijska istraživanja o bitstvu čovječje slobode, str. 20-21.

82

F. W. J. Schelling, Dobā svijeta, str. 21
83

F. W. J. Schelling, IPU, str. 64.

84

F. W. J. Schelling, Filozofijska istraživanja o bitstvu čovječje slobode, str. 31.

85

Usp. F. W. J. Schelling, IPU, str. 66; usp. F. W. J. Schelling, SW I/9, str. 245

86

F. W. J. Schelling, IPU, str. 54; F. W. J. Schelling, SW I/9, str. 237.

87

Usp. M. Cipra, Metamorfoze metafizike, str. 52-53. 
Izvorna lučba, koja je razlučila prajedinstvo iskonskoga stanja na apsolutni subjekt, odnosno A, koje teži samo sebe ponovno uspostaviti u onom B = A, tj. u onom samoga sebe znajućem, prisilno je stanje. Apsolutni subjekt nalazi se u takvoj razlučenosti koja je postala apstraktna i u kojoj on ne može ostati. Ono A je beskonačna mogućnost znanja, a da ipak u sebi nema ništa od zbiljnosti znanja. Zato ga se hoće prisjetiti i njime ispuniti prazninu u sebi. Upravo se iz tog razloga apsolutni subjekt trudi ponovno zadobiti vlastitu nutarnjost, ispunjenje koje se nalazi u onom B. Time apsolutni subjekt više ne bi bio puko čisti subjekt odnosno znanje koje ne zna. Zato se apsolutni subjekt mora ponovno prisjetiti, odnosno opet internalizirati vlastito od njega odvojeno znanje, koje je uistinu prethodno tomu bilo njegov subjekt i njegovo znanje. Tako apsolutni subjekt ne bi više bio držan u pukoj apstrakciji, nego bi postao konkretan i znanjem ispunjeni subjekt.

»Ali sada biva A, taj apsolutni subjekt, u svojoj apstrakciji očuvan samo uz pomoć B, uz pomoć prisile ne znajućega znanja, koje se odriče svakoga znanja. ${ }^{88}$

Taj apsolutni subjekt Schelling je označio i kao mudrost samu, koja je biblijskim rječnikom proglašena onim najpokretljivijim i neuhvatljivim zato što je pokretljivost sama. Apsolutni subjekt valja razlikovati od Boga, ali i Bog je kao apsolutni duh zapravo apsolutni identitet vlastite egzistencije i svoga temelja. Poimanje Boga pretpostavlja prevladavanje opreke između sistema realizma i idealizma.

»Tako je izvjesno da je samo vezom Boga s prirodom u njemu utemeljen personalitet, da je nasuprot tome Bog čistog idealizma, isto kao i Bog čistog realizma, nužno jedno nepersonalno bitstvo, o čemu su Fichteov i Spinozin pojam najjasniji dokazi.« ${ }^{89}$

Upravo zato što je apsolutni subjekt kao vječna sloboda takav, njemu suprotstavljeno znanje ima ga kao pojam, ali pojam koji je jači, životniji i snažniji od takvoga znanja čiji je on pojam. Nikakvo kretanje ne može prethoditi u apsolutnom subjektu kao pokretljivosti samoj, a da to isto ne bude ogledano u B, u pojedinačnoj svijesti čovjeka. B se tako pokazalo kao ono moderirajuće kretanja toga A. Upravo se zato znanje čovjeka, odnosno filozofijsko znanje, postavlja spram apsolutnog subjekta kao zadržavajuća i sputavajuća snaga koja postojano prati nezaustavljivo kretanje apsolutnoga subjekta prema ponovnom uspostavljanju prajedinstva i prasvijesti.

»Tomu nasuprot, odnosi se sada ne znajuće znanje toga kretanja prema njemu kao zaustavljajuća, retardirajuća snaga. Jer upravo zato što je on očuvan u onoj apstrakciji samo prisilom ne znajućega znanja, upravo zato ne može se on kretati, kako se uobičajeno kaže, bez znanja i volje toga znanja, koje se neće odreći slobode neznanja i na taj je način moje znanje kretanje slobodnog svjedoka koji mirno pregledava i prati korak po korak. « ${ }^{90}$

Schelling ponovno jasno naglašava da pitanje o čovjekovoj mogućnosti znanja tog kretanja apsolutnog subjekta nije ispravno, jer su uvijek to kretanje i naše znanje toga kretanja, kao i moment kretanja i naše znanje toga momenta, zapravo jedno te isto. Istinsko filozofijsko znanje tako je ono znanje koje zadržava, retardira i reflektira kretanje apsolutnoga subjekta kao pokretljivosti same. Ništa osim toga filozof nema pravo prisvajati i nazivati svojim u filozofiji.

»Zato što je samo kretanje u potpunosti neovisno o njemu, i - što je veoma važno - ne pokreće on sebe u svom znanju i time rađa znanje (neko takvo rođeno znanje subjektivno je, neko puko pojmovno znanje, bez realiteta), nego upravo suprotno, njegovo je znanje po sebi nepokretno, nije puko neznanje, nego je ono koje se suprotstavlja znanju, ono koje se opire kretanju, ono koje zadržava kretanje, ono što ga u svakom momentu prisiljava da ima držati mjesto, zadržati ga i nijedno ne preskočiti. «91 
Snaga pojedinog filozofa otkrivena je jedino kroz umijeće sputavanja i zaustavljanja, a ne pokretanja nečega pomoću vlastite snage. Filozofija nužno mora postavljati sebe spram apsolutnog subjekta, a onaj koji je više u filozofiji od drugoga, odnosno onaj koji je veći umješnik u filozofiji imat će i veću snagu zadržavanja i sputavanja nego snagu pukoga produciranja, tjeranja i požurivanja..$^{92}$

\section{Zaključak}

Pravi sadržaj Schellingova srednjega razdoblja pitanje je o statusu i naravi filozofije kao znanosti. Da bi se filozofija mogla kao znanost uspostaviti i konstituirati, potrebno je da ona zadobije formu sistema. Jedino ono što je u sistemu može imati težinu i biti u potpunosti shvaćeno jer u tom slučaju biva shvaćenim na sebi primjerenom mjestu. Samokonstituiranje filozofije kao znanosti omogućeno je apsolutnim subjektom koji u prolasku svim obličjima znanja uspostavlja totalni sistem kao sistem svih mogućih partikularnih sistema. Apsolutni subjekt kao sama sebe pokrećuće i napredujuće kroz sva partikularna obličja po svome bitstvu jest vječna sloboda po kojoj se može zatvoriti u neko obličje i potom po vlastitoj volji iz njega izaći. Kretanje od jednoga obličja do drugoga istinski je sadržaj filozofije kao znanosti, a ona pak svoju svrhu ispunjava tako da vjerno prati to kretanje subjekta. Onaj koji jedini može pratiti to kretanje, jer ga već ima reflektiranoga u sebi, jest čovjek kao princip partikularne svijesti koji u sebi posjeduje zaustavljajuće i zadržavajuće znanje, koje se uvijek postavlja nasuprot kretanju apsolutnoga subjekta kao principa univerzalne svijesti. Svako kretanje apsolutnoga subjekta kao vječne slobode uočljivo je u nutarnjosti samoga čovjeka. Izlazak apsolutnoga subjekta iz stanja neznanja u stanje znanja analogno je povratku čovjeka i njegove subjektivne svijesti u univerzalnu svijest. Svaki takav događaj potrebuje nikad raskidivu i postojanu napetost između čovjeka i apsolutnog subjekta, partikularne i univerzalne svijesti.

Čovjek u stanju znanja onaj je koji jedini u sebi ima slobodno mišljenje kao putokaz, ali i neutaživu težnju i čežnju za uspostavom ponovnoga jedinstva s apsolutnim subjektom odnosno mudrošću samom u nekadašnjem jedinstvu prasvijesti. Postojana napetost, poput polova u magnetu, između apsolutnoga subjekta i čovjeka kao onoga subjektivnoga znanja nužna je kako bi kretanje napredovalo. Prestanak napredovanja u ponovnoj ujedinjenosti apsolutnoga subjekta, ali tada kao potpunoga znanja, i čovjeka, ali tada kao znajućega neznanja onog apsolutnog subjekta, ne znači i prestanak kretanja. Navlastito kretanje uvjet je svakom životu pa makar i ne bilo više daljnjega napredovanja u potpunom sjedinjenju onoga sasvim nutarnjega i onoga sasvim izvanjskoga. Kretanje je to koje apsolutni subjekt kao vječna sloboda poduzima kako bi ponovno stekao znanje o samome sebi, odnosno putovanje je to apsolutnoga subjekta prema samospoznaji, a time ujedno reflektirano i kao putovanje čo-

88

F. W. J. Schelling, IPU, str. 54; F. W. J. Schelling, SW I/9, str. 237.

89

F. W. J. Schelling, Filozofijska istraživanja o bitstvu čovječje slobode, str. 53.

90

F. W. J. Schelling, IPU, str. 55; F. W. J. Schel-

ling, SW I/9, str. 237-238.
91

F. W. J. Schelling, IPU, str. 55; F. W. J. Schelling, SW I/9, str. 238

92

Usp. ibid. 
vjeka prema samospoznaji, koja slovi kao najviši zakon i zapovijed mudrosti. Takvo putovanje uistinu može biti poduzeto samo iz ljubavi prema vječnoj mudrosti. Ljubav prema mudrosti određena je cjelinom svega što jest jer ništa joj u njenom ljubljenju ne izmiče. Upravo je to opisani proces uspostave filozofije kao duhovne znanosti u obliku sistema.

\title{
Ivan Smiljanić
}

\section{Philosophie als Geisteswissenschaft in Schellings mittlerer Periode}

\begin{abstract}
Zusammenfassung
In dieser Arbeit wird vorgestellt die Entwicklung einer notwendigen Idee des Systems, die die wahre Form der Philosophie als Wissenschaft darstellt, wie es in Schellings späterem Denken, besonders während seiner Erlangen Vorlesungen von 1821 ausgeführt wurde. Schelling zeigt, dass das absolute Subjekt, das sich von einer Wissensform zur anderen bewegt, das über alle bestimmten Systeme erhobene Totalsystem bildet, und dadurch die Selbsterkenntnis erlangt, welche der wahre Inhalt der Philosophie als Wissenschaft ist. Das wahre philosophische Wissen ist das, was sich der Bewegung des absoluten Subjekts widersetzt, wodurch das menschliche Bewusstsein als das Bewusstsein des absoluten Subjekts ausgebildet wird. Nur die Philosophie als Wissenschaft kann den Menschen zur höchsten Wissen über das Bewusstsein des absoluten Subjekts als sein eigenes Bewusstsein führen und bringen.
\end{abstract}

\section{Schlüsselwörter}

Friedrich Wilhelm Joseph Schelling, Absolutes Subjekt, Philosophie, Wissenschaft, Weisheit, Freiheit, System, Ekstase, Bewusstsein, Mensch, Geist 